\title{
EZER ESZTENDŐ MAGYAR REBELLISEI
}

Romsics Ignácot eredetileg a 20. századi magyar történelemmel, szükebben véve mint a Horthy-korszakkal foglalkozó jeles kutatót ismerte meg a történész céh, illetve a hazánk múltja iránt érdeklődők szélesebb köre. Az 1970-es évek derekán a Duna melléki ellenforradalomról írt dolgozatával kezdődött pályája, amit a Horthy-rendszer első tíz évéről szóló összegzése, továbbá a Duna-Tisza közének 1918-19-es hatalmi viszonyait bemutató könyve követett. E müvek hozzájárultak az akkori történetpolitikai kánon lebontásához. 1991-ben mintaszerủ életrajzot publikált gróf Bethlen István miniszterelnökröl, az elkövetkezendö években pedig sorra közölte alapvetésnek tekintett müveit Trianonról, az 1947-es párizsi békeszerződésről vagy éppen Magyarország 20. századi történelmének szintéziséröl.

Az utóbbi esztendőkben Romsics érdeklődése történelmünk korábbi századaira is kiterjedt. Ennek köszönhetően 2015-ben a Múlt arcai címmel a magyar história kilenc, mindmáig vitatott eseménye és személyisége körül kialakult diskurzust mutatta be, míg 2017 őszén jelent meg tollából a nagy sikerü Magyarország története, melyben a teljességre törekedve, az uráli őshazától napjainkig foglalta össze népünk történelmét. Legutolsó könyvét életmüsorozatának keretében a Helikon Kiadó jelentette meg, Magyar rebellisek címen, 2019 októberében.

A 449 oldalas kötet történelmünk tizenegy lázadó csoportját mutatja be időrendi sorrendben, Szent István király riválisaitól és az utolsó pogányoktól kezdve egészen az 1989-es rendszerváltókig. A szerző mindegyikük esetében - a forrásadottságok arányában - három alapvető kérdés megválaszolására törekedett: 1 . Kik voltak, honnan jöttek a felkelők? 2. Mi okból lázadtak fel? 3. Mire törekedtek, mik voltak a céljaik?

Romsics könyvéböl megállapítható, hogy a magyar rebellisek elsősorban - természetesen az adott kortól, valamint a politikai-társadalmi környezettől függően a vallási, rendi vagy polgári szabadságjogok védelmében, az ország függetlenségének helyreállításáért, továbbá a társadalmi modernizáció érdekében léptek fel. István király ellenfelei a kereszténység terjesztését és az uralkodó főhatalmát veszélyeztették, míg a 11. századi utolsó pogányok a régi hitvilág visszaszorításával, illetve a kereszténység meggyökereztetésével helyezkedtek szembe. A középkori parasztfelkelők elsődlegesen az adóterheik mérséklését és a szabad költözés jogának biztosítását kívánták elérni. A székely lófők és közszabadok szemében a régi kiváltságaik, autonómiájuk és adómentességük megőrzése volt a cél. Hajdúi élén Bocskai István főképpen a protestáns vallásszabadság kivívásáért szállt síkra. A Wesselényi Ferenc-féle föúri összeesküvők harcoltak a tö- 
rökkel szemben, Habsburg-ellenesek voltak, és a három részre szakadt ország egységesítése érdekében érintkezésben álltak Párizzsal és Isztambullal is. Rákóczi Ferenc az 1707-es ónodi országgyülésen detronizáltatta a Habsburgokat, valamint egyesítette Erdélyt Magyarországgal, míg az 1708-as sárospataki diétán személyi szabadságot ígért a katonáskodó jobbágyoknak és azok kiskorú fiainak, miközben az általuk lakott településeknek meg kívánta adni a hajdúvárosoknak járó előjogokat. A szerző által a „polgári átalakulás előhírnökeiként” jellemzett magyar jakobinusokat a rendiség lebontásának, illetőleg a polgári magyar állam megteremtésének törekvése vezette. S bár ők a bécsi udvar fellépése, majd a megtorlás miatt ezt képtelenek voltak véghezvinni, a történelem kerekét már nem lehetett visszaforgatni, s 1848-ra, köszönhetően többek között a kötetben is szereplö márciusi fiataloknak, sikerült megvalósítani a polgári átalakulás programját. Az 1919-es bolsevista népbiztosok Közép-Európa első szovjet típusú hatalmában a kommunizmus megvalósítását tűzték zászlajukra. Az 1956-os felkelővezérek mindenekelőtt az önkényuralom megbuktatásáért, valamint hazánk függetlenségének visszaszerzéséért harcoltak. Bő három évtizeddel később, az 1989-es rendszerváltók programjában is hangsúlyos szerepet kapott a diktatúra felszámolása, és az ország szabadságának visszaállítása, miközben két nagy áramlatuk közül az urbánus csoport az emberi és állampolgári jogok védelmét, kiteljesítését tekintette alapvetőnek, míg a népi szárny a határon túli magyar kisebbségek helyzetét, továbbá az ún. „magyar sorskérdések” (népességfogyás, alkoholizmus, öngyilkosságok stb.) ügyét.

A forrásadottságok magyarázzák, hogy a tizenegy lázadó csoport közül a három 20. századiról Romsics közel akkora terjedelemben (183 oldalon keresztül) értekezik, mint a 11. és 19. század közötti másik nyolcról (230 oldal). Az 1919-es népbiztosokat több szempont (származás, vallás, szociális háttér, iskoláztatás, foglalkozás) szerint vette górcső alá, s arra a megállapításra jutott, hogy a Magyarországi Tanácsköztársaság 133 napja alatt népbiztosi feladatokat betöltő harmincöt személy túlnyomó többségét csak egyvalami rokonította: kötődésük a Magyarországi Szociáldemokrata Párthoz, illetve szakszervezeteihez. A harmincöt fö közül huszonhármat (65,7\%-ukat) anyakönyvezték izraelitaként, viszont a proletárdiktatúra zsidó származású vezetői nem vallási vagy etnikai megfontolásból, hanem elsődlegesen az „osztálytudatuk” miatt csatlakoztak a bolsevista mozgalomhoz. 42,8\%-uk rendelkezett egyetemi diplomával, és a harmincötből huszonketten (tehát 63\%-os arányban) ,fehérgallérosként”, azaz a kezdetektöl fogva értelmiségiként dolgoztak közülük. Eörsi László történész alapkutatásaira hivatkozva a szerző hasonló részletességgel tárja elénk az 1956-os forradalom és szabadságharc felkelővezéreinek portréit is, melyekben a szélesebb olvasóközönség számára eddig jobbára ismeretlen tények is szerepelnek: nyolcvanhat személyről rendelkezünk összehasonlító adatokkal, akik mindegyike férfi volt. Közülük huszonegyen vettek részt a második világháborúban, és nyolcan a 
keleti fronton hadifogságban is voltak, így egyrészt érhető módon ellenszenvvel viseltettek a szovjetek iránt, másrészt könnyedén fogtak fegyvert, ha arra került a sor. 1956 elött közülük öten politikai okokból, huszonhatan pedig köztörvényes vétségek miatt szembekerültek már az igazságszolgáltatással. A forradalom és szabadságharc leverése után az életben maradt nyolcvannégy parancsnokból harmincnégy hagyta el az országot, de közülük rövid időn belül nyolcan visszatértek az emigrációból. Az '56-os rebelliseket követő fejezet „hőseiből”, a '89-es rendszerváltókból Romsicsnak nem sikerült egy olyan jól körülhatárolható csoportot létrehoznia, amelyet prozopográfiai elemzésnek vethetett volna alá, ezért esetükben azt a megoldást választotta, hogy az eseménytörténet bemutatása mellett az átalakulás ikonikus alakjairól (Antall József, Csoóri Sándor, Göncz Árpád, Kis János, Orbán Viktor, Pozsgay Imre stb.) szürke keretben hosszabb-rövidebb mikrobiográfiákat közölt.

A Magyar rebellisek borítóját a Helikon Kiadó Romsics-életmüsorozatának többi darabjához hasonlóan a fehér-fekete-arany színek dominálják. Az egyszerü, ámde igényes előoldalon idősebb Georg Philipp Rugendas német festő-rézmetsző kuruc lovast ábrázoló metszete csábítja az olvasót arra, hogy leemelje a kötetet a könyvesbolt polcáról. Noha erről természetesen nemcsak a külcsín, hanem a beltartalom is gondoskodik: a mű nyelve a szerzőre jellemzően gördülékeny és olvasmányos, a felhasznált szakirodalom mennyisége, valamint az abból leszürt tényanyag alapossága pedig imponáló. Mindezek fényében bizton állítható, hogy Romsics Ignác legújabb könyve nemcsak a szüken vett történészi szakma, hanem a magyar történelem iránt érdeklődők lehető legszélesebb körének figyelmére és elismerésére is számot tarthat.

(Romsics Ignác: Magyar rebellisek. Budapest: Helikon Kiadó, 2019, 449 o.)

Gali Máté

tudományos munkatárs VERITAS Történetkutató Intézet és Levéltár 